\title{
Analysis of long-time operation of micro-cogeneration unit with fuel cell
}

\author{
Marek Patsch ${ }^{1, a}$ and Alexander Čaja ${ }^{1}$ \\ ${ }^{1}$ University of Žilina, Faculty of Mechanical Engineering, Department of Power Engineering, Univerzitná 1, 01026 Žilina, Slovakia
}

\begin{abstract}
Micro-cogeneration is cogeneration with small performance, with maximal electric power up to 50 $\mathrm{kW}_{\mathrm{e}}$. On the present, there are available small micro-cogeneration units with small electric performance, about $1 \mathrm{~kW}_{\mathrm{e}}$, which are usable also in single family houses or flats. These micro-cogeneration units operate on principle of conventional combustion engine, Stirling engine, steam engine or fuel cell. Micro-cogeneration units with fuel cells are new progressive developing type of units for single family houses. Fuel cell is electrochemical device which by oxidation-reduction reaction turn directly chemical energy of fuel to electric power, secondary products are pure water and thermal energy. The aim of paper is measuring and evaluation of operation parameters of micro-cogeneration unit with fuel cell which uses natural gas as a fuel.
\end{abstract}

\section{Introduction}

The cogeneration means combined production of heat and electric power (CHP - Combined Heat and Power). Combined production of heat and power is one of the best way how to utilize chemical energy which is contained in fuel. Micro-cogeneration is cogeneration with small performance, with maximal electric power up to $50 \mathrm{~kW}_{\mathrm{e}}$.

Till now, all devices on the market offered technologies for single family houses which provide separated heat production (condensing boiler, heat pump, solar collector,...) or electric power production (photovoltaic panel, small hydroelectric power plant, wind power plant,...). On the present, the market offers micro-cogeneration units (micro-CHP) with small performance - electric power about $1 \mathrm{~kW}_{\mathrm{e}}$, which can be used in single family houses. These devices operate on the principles of combustion engine, Stirling engine, steam engine, or on the principle of fuel cell. These micro-cogeneration units produce thermal power up to 20 $\mathrm{kW}_{\mathrm{t}}$ and electric power up to $5 \mathrm{~kW}_{\mathrm{e}}$. The main fuel used in micro-cogeneration for single family houses is natural gas.

The usage philosophy of these units is in production of thermal energy for heating and for preparation of domestic hot water and electric power acquirement is as a bonus. Produced electric power is generally for home consumption, not for sale into distribution grid. Electric output of these units is satisfactory to cover house consumption; in the case of higher consumption the electric power is bought from distributor.

The main problem in micro-cogeneration is amount of operating hours which influence on pay-back period of purchase costs. The harmonization of heat and electric power requirement have main influence on operate hours.
The problem is partly minimized by using of the heat accumulating tank. Micro-CHP unit can partly work in case when we need electric power without thermal power at the same time. Next problematic season is summer when we need heat only for preparation of domestic hot water but electric power requirement is practically constant during all year. This season reduces quantity of micro-cogeneration unit operation time and thereby extends pay-back period. The ideal working condition is continuous running of unit during all year. Insufficiency of some technologies especially fuel cells is low thermal production, it means requirement of extra heat source. This heat source covers peak heat demand.

\section{Fuel cells}

The fuel cell is electro-chemical device which transforms chemical energy of fuel directly into electric power by means of oxidizing-reduction reaction. The main fuel for fuel cells is hydrogen which can be supplied in pure form or in form which hydrogen contains (gaseous or liquid), most commonly it is methane or methanol. If the fuel cell should be used as a power source at homes in Slovakia, the most preferred fuel will be natural gas, because it has the favorable ratio between hydrogen and carbon and due to largely gasification of Slovakia. As an oxidizer is most commonly used pure oxygen or oxygen in the air. Electro-chemical reaction in fuel cell produces direct current, and heat and water as a secondary product.

The fuel cells have different types of electrodes material, used electrolyte, working temperature and chemical reactions on the electrodes. The fuel cells are divided into three main categories by working

\footnotetext{
${ }^{\mathrm{a}}$ Corresponding author: marek.patsch@fstroj.uniza.sk
} 
temperature and these categories are divided into six groups by used electrolyte.

Fuel cell with low working temperature $\left(60-120^{\circ} \mathrm{C}\right)$

- AFC - Alkaline Fuel Cell

- PEMFC - Polymer Electrolyte Membrane Fuel Cell

- DMFC - Direct Methanol Fuel Cell

Fuel cell with middle temperature $\left(160-200^{\circ} \mathrm{C}\right)$

- PAFC - Phosphoric Acid Fuel Cell

Fuel cell with high working temperature (600$\left.1000^{\circ} \mathrm{C}\right)$

- $\mathrm{MCFC}$ - Molten Carbonate Fuel Cell

- $\mathrm{SOFC}$ - Solid Oxide Fuel Cell

\subsection{SOFC}

The fuel cells types of PEM, DMFC and SOFC are most commonly used in micro-cogeneration units. The most favorable is using of high temperature SOFC fuel cells in term of heat production for heating and preparation of domestic hot water. But high working temperatures mean high demands on materials of fuel cells.

The SOFC consists of electrolyte disc which has deposited material of anode and cathode on its sides. The separate fuel cells are connected to bundle in order to reach required electric power. The individual fuel cells are separated by metallic connection parts which serve to supply and divide gas and air.

Fuel for fuel cells is generally pure hydrogen or natural gas. Using of natural gas is better solution for fuel cell in home; however natural gas have to be without sulfur. Sulfur can intoxicate catalytic material of reformer in the fuel cell and it ultimately can cause destruction of fuel cell device. For natural gas using in fuel cells is necessary to applying process called reforming. Reforming of natural gas is process how to obtain hydrogen from natural gas molecule $\mathrm{CH}_{4}$. This process can be done by steam reforming or partial oxidation of $\mathrm{CH}_{4}$.

\subsection{Operation principle of SOFC}

The operation principle of SOFC which is used in micro-cogeneration unit is shown in next figures. Filtered air blow into fuel cell (fig.1). Air flows among individual metallic connection parts from cathode sides of fuel cells (fig. 2). Fairly filtered natural gas $\mathrm{CH}_{4}$ is mixed with secondary air outside of fuel cell module. This mixture flows through catalyser where catalytic partial oxidation occurs. The result of the reaction is mixture of $\mathrm{H}_{2}, \mathrm{CO}$ and not-reacted part of $\mathrm{CH}_{4}$. This mixture flows into fuel cells module along axis of fuel cells. Mixture flows among individual connection metallic parts from anode sides (fig.3). Electro-chemical reaction between this mixture and fresh air occurs in fuel cells, the direct current, heat and water are produced. Residuum of reaction (not-reacted part of $\mathrm{CH}_{4}$ and rest of air) flows at the edge of fuel cells. There is the afterburning zone (fig. 4). The residuum burns in afterburning zone at high temperature (about $1000^{\circ} \mathrm{C}$ ). After that, exhaust gases comes into heat exchanger where pass heat energy to heating water.

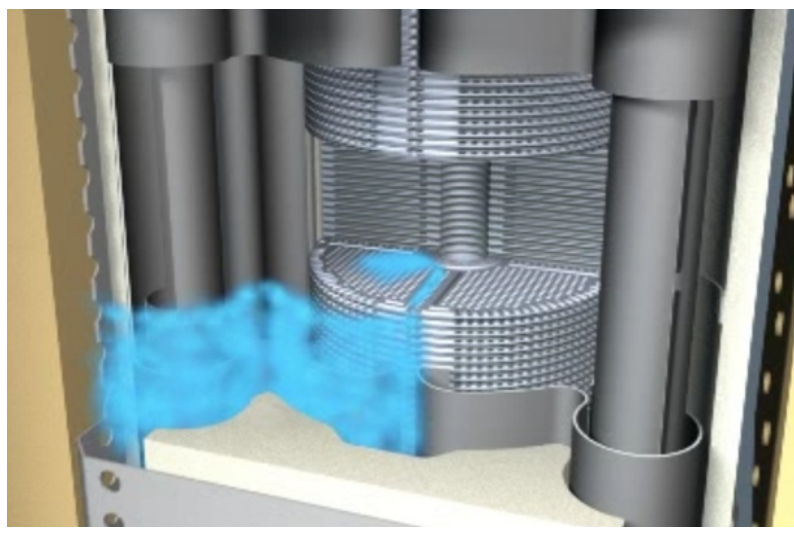

Figure 1. Operation principle of SOFC - air inlet [1].

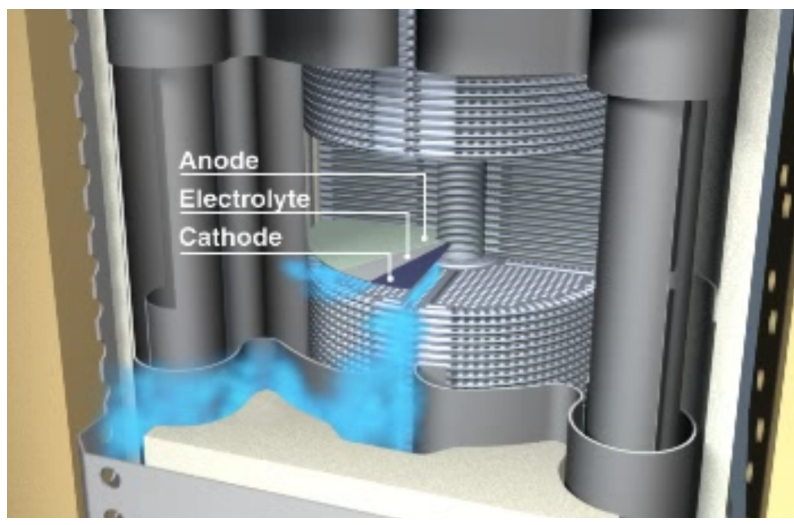

Figure 2. Operation principle of SOFC - anode, electrolyte and cathode [1].

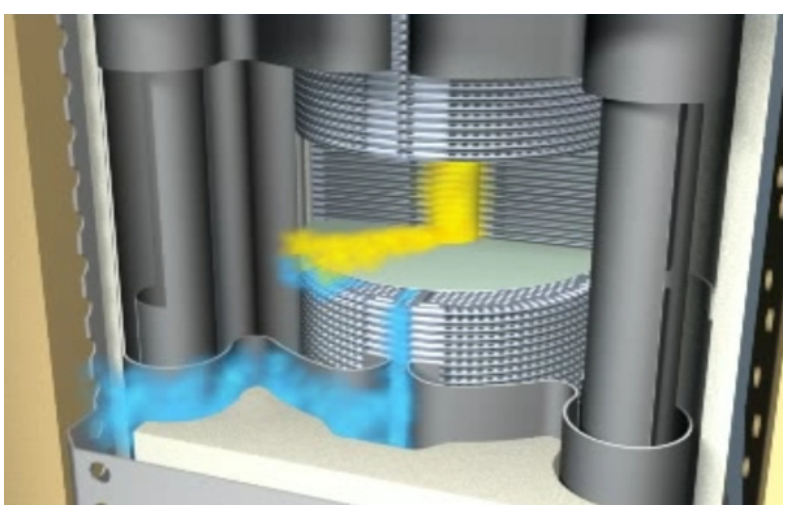

Figure 3. Operation principle of SOFC - mixture inlet [1].

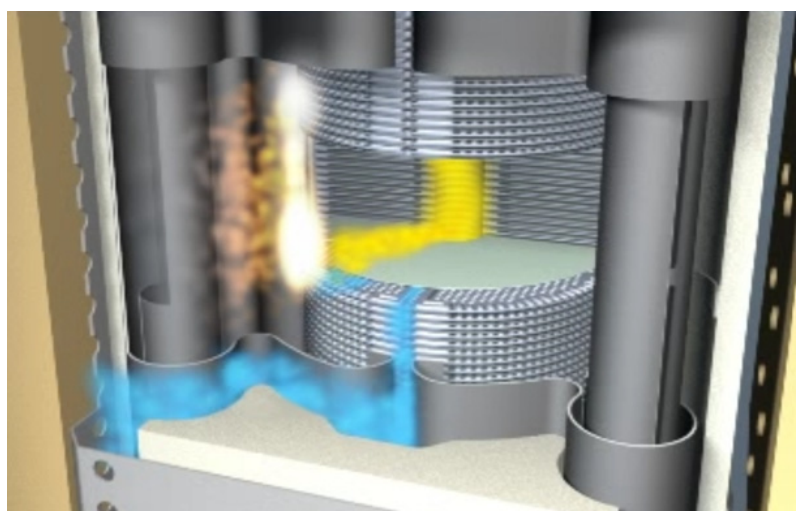

Figure 4. Operation principle of SOFC - afterburning zone [1]. 


\section{Micro-cogeneration unit with fuel cells}

Till now, the most frequently usage of fuel cells is in telecommunication, military and space technology, eventually as a back-up power supply with high performance. The usage of fuel cells in microcogeneration is not extended, the most of manufacturers are under test and development. These devices are primarily commercially available in Japan, USA and some states in Europe (Deutschland, Switzerland,...). Financially demanding development of these devices and price of applied materials in fuel cell resulting in a high purchase and it resulting low expansion of these microcogeneration units with fuel cells.

Tested micro-cogeneration unit utilizes fuel cell with SOFC technology (high temperature fuel cell with operation temperature about $870^{\circ} \mathrm{C}$ ). Fuel cell module is located in top of unit (fig.5), the module consists of 61 separated fuel cells which are connected into series (due to reach required electric performance). The module has nominal electric power $1,0 \mathrm{~kW}_{\mathrm{e}}$ and heat input from 1,8 up to $3,3 \mathrm{~kW}_{\mathrm{t}}$.

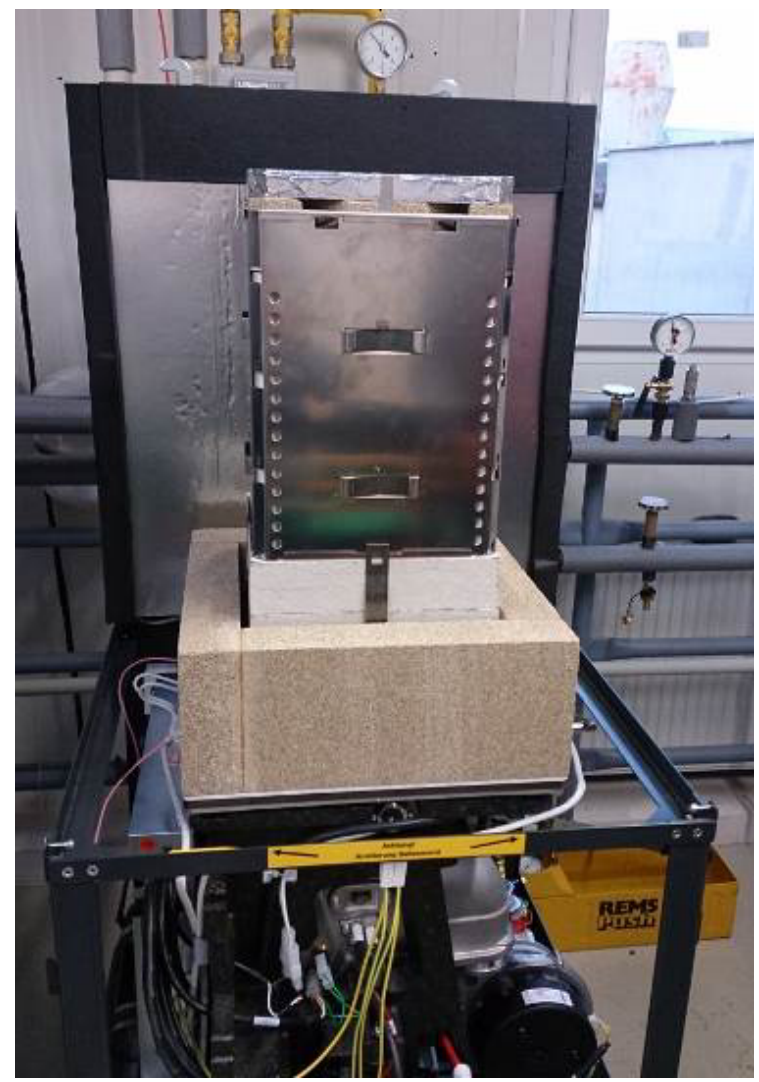

Figure 5. High temperature SOFC.

The device is supplemented by condensing boiler (fig. 6) with heat input from 7,0 up to $20,0 \mathrm{~kW}_{\mathrm{t}}$, the condensing boiler covers increased heat demand. The device is able to operate in fuel cell mode, condensing boiler mode, or fuel cell with condensing boiler mode. Low heat input of fuel cell with accumulation storage tank allows practically continuous operation. The unit (fig. 7) uses natural gas as a fuel, hydrogen from natural gas is obtained by partial oxidation of $\mathrm{CH}_{4}$.

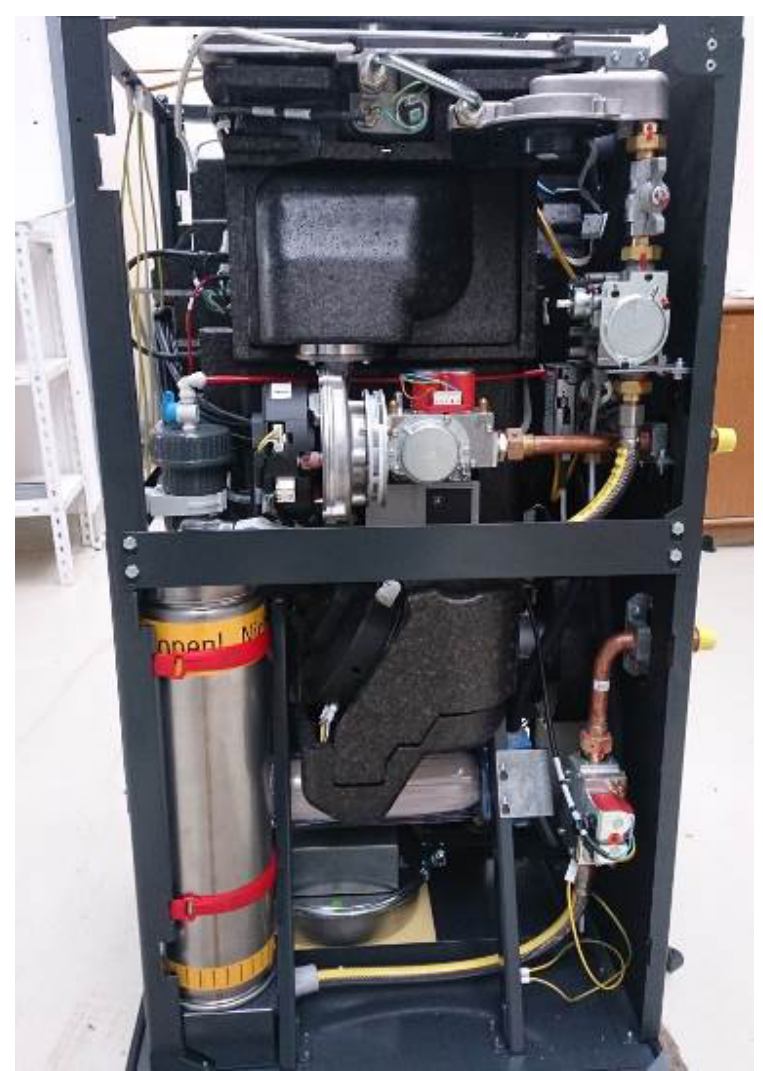

Figure 6. Micro-cogeneration unit without cover.

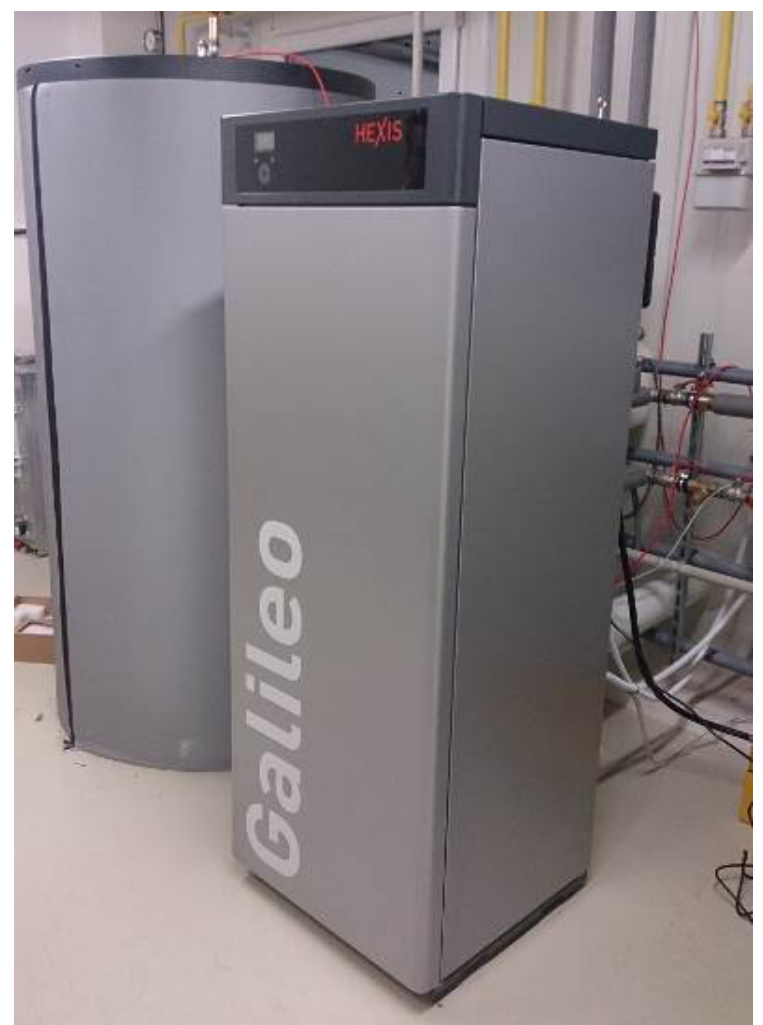

Figure 7. Micro-cogeneration unit with heat storage tank.

\section{Measuring of operation parameters}

The measuring during normal condition of operation is not the aim of the article. The measuring was especially during specific condition of operation. The first important 
condition was start and slope to nominal electric power of unit. The second important condition was simulated power cut in outer electrical power network. The measuring was under temperature gradient $75 / 25^{\circ} \mathrm{C}$. Measured parameters were:

- Input and output temperature of heating water, its flow. Measured parameters were used for calculation of thermal input.

- Natural gas consumption and its parameters which were used for reference conditions adjustment.

- Electric input and output of the unit.

The electric power from micro-cogeneration unit is supplying into laboratory electric grid and thermal energy is spoiling in hot-fan unit. Electric power input and output were measured through two-way electronic wattmeter.

The figure 8 shows measured and computed data during start and slope to nominal electric power of unit. After start, fuel cell module was heat-up to operation temperature $870^{\circ} \mathrm{C}$. The heat-up was realized by electric preheaters. The electric preheaters consumed electric power from outer electric power network. Their electric input was about $1450 \mathrm{~W}_{\mathrm{e}}$ and this stage took about 8 hours. was stopped. The electric power production of fuel cell module was not stable until the device reached nominal electric power. Nominal electric power $1000 \mathrm{~W}_{\mathrm{e}}$ was reached 45 hours after device activation. Since that, the device consumed about $25 \mathrm{~W}_{\mathrm{e}}$ from outer electric power network, this electric energy was for synchronize the device with outer electric network.

The figure 9 shows measured and computed data during simulated power cut in outer electric power network. During this operation condition the device cut down electric power immediately from $1000 \mathrm{~W}_{\mathrm{e}}$ to $0 \mathrm{~W}_{\mathrm{e}}$. The device was switched to stand-by mode (during this condition the fuel cell module continually produced about $200 \mathrm{~W}_{\mathrm{e}}$ for self-consumption and for water circulation pumps - the micro-cogeneration unit is able to supply house with thermal energy continually when outer electric power network is cut down). When outer electric power network was renewed, the micro-cogeneration unit started slope to nominal electric power $1000 \mathrm{~W}_{\mathrm{e}}$. It took about 2,5 hours. The course of thermal energy output was nearly constant, slow increase was during stand-by mode. It was due to chilling of fuel cell module. Electric power consumption from outer electric power network during switch on from stand-by mode was due to switching on

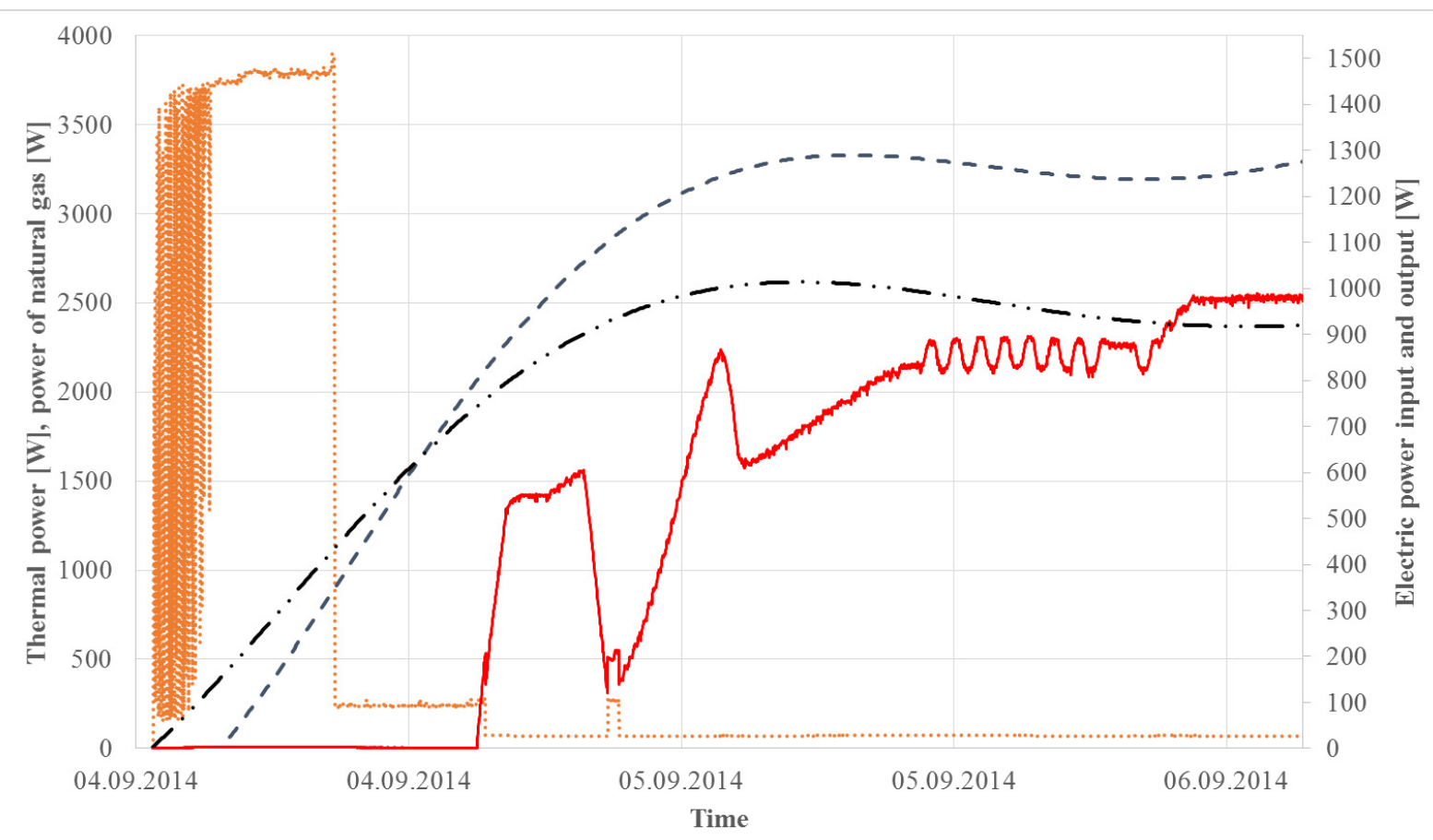

…... Electric power input $[\mathrm{W}]$ Electric power output $[\mathrm{W}]$ - - Power of natural gas $[\mathrm{W}]$ — $\cdot$ Thermal power [W]

Figure 8. The course of electric power input and output, thermal power and power of natural gas during start of microcogeneration unit.

During this stage, the input of natural gas started, but fuel cell module did not produce the electric power. Thermal power slowly increased. Production of electric power stated 14,5 hours after device activation. When production of electric power started, electric preheating electric preheaters to reach operation temperature $870{ }^{\circ} \mathrm{C}$ of fuel cell module. Second reason is fact that during switch on from stand-by mode, all systems of device are powered by outer electric power network. 


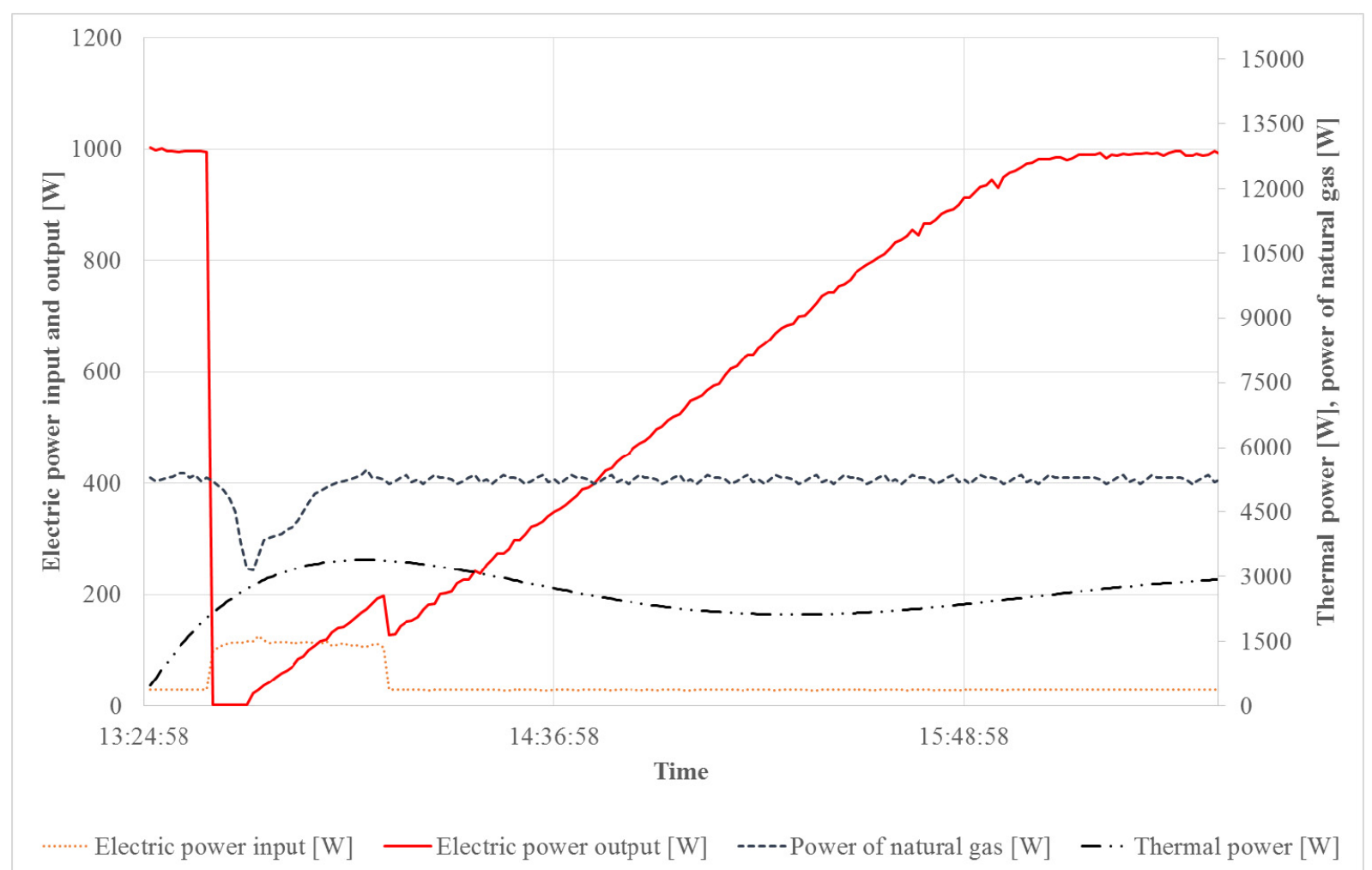

Figure 9. The course of electric power input and output, thermal power and power of natural gas during simulated power cut in outer electric power network.

\section{Conclusions}

Micro-cogeneration with fuel cell which uses natural gas as a fuel is high sophisticated technology of combined produce of heat and electric power. The usage philosophy of these units is in production of thermal energy for heating and for domestic hot water preparation and electric power acquirement is generally for home consumption, not for sale into distribution grid.

The measuring shows courses of electric power input and output, heat input and power supplied by natural gas during some specific conditions. The measuring shows that micro-cogeneration unit is able to supply home with electric power and in combination with integral condensing boiler also with thermal energy. The device behaviour during start shows long slope to nominal electric power $1000 \mathrm{~W}_{\mathrm{e}}$. This means that continuous operation is better for energy production of microcogeneration unit. The device behaviour during simulated power cut in outer electric power network shows long slope to nominal electric power $1000 \mathrm{~W}_{\mathrm{e}}$. This means that the micro-cogeneration unit is not resilient source of electric energy. The next measurement will be oriented on lifetime of fuel cell and relationship between electric efficiency and operation time.

The micro-cogeneration units with fuel cells have perspective to progressive expansion, but financially demanding development of these devices and price of applied materials in fuel cell resulting in a high purchase and it resulting low expansion of these devices.

\section{Acknowledgments}

This article was created within the frame of project KEGA 070ZU-4/2013 "Modern sources for heating" („Moderné zdroje pre vykurovanie“).

The research is supported by the European Regional Development Fund and the Slovak state budget for the project "Research Centre of University of Zilina", ITMS 26220220183.

\section{References}

1. Technical documentation of micro-cogeneration unit Hexis Galileo $1000 \mathrm{~N}$

2. M. Pehnt, M. Cames, C. Fischer, B. Praetorius, L. Schneider, K. Schumacher, J.P. Voß, Micro Cogeneration, Towards decentralized energy systems (Berlin, Springer, 2006)

3. J. Hužvár, J. Jandačka, P. Pilát, Proposal of microcogeneration unit with biomass combustion (Experimental fluid mechanics 2008: International conference, November 26-28, 2008, Liberec, Czech Republic, conference proceedings - Liberec: Technical University, 2008)

4. M. Vantúch, A. Kapjor, M. Malcho, J. Hužvár, Š. Papučík, Operational measurement of ground/water heat pump in cold weather (Structure and environment: architecture, civil engineering, environmental engineering and energy. Vol. 5, no. 2/2013, s. 40-42) 